\title{
Determination of the Undrained Shear Strength of Sensitive Clay Using Some Laboratory Soil Data
}

\author{
Tahar Ayadat \\ Correspondence: Tahar Ayadat, Associate Professor, Prince Mohammad Bin Fahd University, Al-Khobar, Saudi Arabia.
}

Received: December 24, 2020

Accepted: January 25, $2021 \quad$ Online Published: February 1, 2021

doi:10.11114/set.v8i1.5149

URL: https://doi.org/10.11114/set.v8i1.5149

\begin{abstract}
The undrained shear strength is a paramount parameter in determining the consistency and the ultimate bearing capacity of a clay layer. This resistance can be determined by in-situ tests, such as the field vane test or by laboratory tests, including the portable vane test, the triaxial, the simple compression test, and the consistency penetrometer test (i.e. the Swedish cone). However, the field vane test and the Swedish cone are the most commonly test used by geotechnical experts. In this paper, relationships between the field undrained shear strength of sensitive clay and some laboratory soil properties were developed. The soil properties consisted of the percentage of fine particles (less than $2 \mu \mathrm{m}$ ), the moisture content and the Atterberg limits. Furthermore, a correlation was proposed associating between the undrained shear strength of sensitive clay as obtained by the field vane test and the laboratory cone penetration test (Swedish cone). In addition, some applications of the proposed correlation on some geotechnical problems were included, such as the determination of the consistency and the bearing capacity of a clay layer. Comparison of the results of the developed correlations with the experimental results of the present investigation and the results reported in the literature show acceptable agreement.
\end{abstract}

Keywords: correlation, shear strength, sensitive clay, soil properties, vane test, Swedish cone

\section{Introduction}

Soil shear strength is one of the most important aspects in geotechnical Engineering. The bearing capacity of shallow or deep foundations, the stability of slopes, and the design of retaining structures are all governed or affected by the shear strength of soils. The design of these different structures requires the determination of the shear strength of soils. This parameter can be determined by in-situ or laboratory tests, including the field vane test, laboratory vane test, triaxial, unconfined compression test, and the consistency penetrometer (noted as the Swedish cone). However, the field vane test and the Swedish cone are the most commonly tests used by geotechnical laboratories. Relatively recent studies have confirmed that the electric field vane test has proven to be an extremely accurate tool for measuring the undrained shear strength of clays (e.g. Tanaka, Hirabayashi, Matsuoka \& Kaneko, 2012; Schaeffers \& Weemees, 2012; Karakan \& Demiri, 2018).

Nevertheless, in situ measurement of shear strength parameters can be difficult, time consuming and costly. For this reason, geotechnical engineers have the tendency to use the existing correlation equations established between this parameters and some soil indices in order to speed-up the design process. Several research works were reported in literature attempting to correlate the field vane undrained shear strength of consolidated and overconsolidated clays with the plasticity index, the Atterberg limits, the compressibility, the pre-consolidation pressure, the SPT, etc. (Among others, Ching \& Phoon, 2004; Obasi \& Anyaegbunam, 2005; Fehmarnbelt, 2011; Jonsson \& Sellin, 2012; Sorensen, 2013; Hernandez-Martinez \& Karlsrud, 2013; Westerberg, Müller \& Larsson, 2015; D’Ignazion, Phoon, Tan \& Lansivaara, 2016; Jacob \& Hari, 2016; D'Ignazion, Phoon, Tan, Lansivaara \& Lacasse, 2017; Persson, 2017; Mengistu, 2017; Cangir \& Dipova, 2017; Chacko \& Jacob, 2018; Karakan \& Demir, 2018; Shimobe \& Spagnoli, 2019; Shimobe \& Spagnoli, 2020).

Likewise, numerous investigations were carried out in order to compare the results of the field vane test and the penetrometer cone test (Swedish cone), notably between those performed to obtain the undrained shear strength of clays (among others, Weemees et al., 2006; Tanaka, Hirabayashi, Matsuoka \& Kaneko, 2012; Schaeffers \& Weemees, 2012). However, little work has been published on the comparison between the results of the undrained shear strength of sensitive cohesive soils determined by the field vane test and the cone penetration test (i.e. the Swedish cone), notably for Champlain clay of the Quebec province area. 
It is exceptional that on the same project all the physical, mechanical and hydraulic parameters of the site are measured together and at the same time. Usually, recognition is limited to certain parameters, depending on the specificity of the project (size, budget, schedule, etc.). In some cases, the undrained shear strength of the clay is either estimated from empirical expressions based on some soil properties or determined in the laboratory and not on site, from a Shelby tube, using the Swedish cone or the portable vane. For this reason, the use of correlations between the physical and mechanical properties of soils determined in laboratory can effectively contribute to the geo technician's synthesis work. Although, significant number of correlations were developed for this purpose as indicated previously, but to the best of our knowledge, there is no such correlation associating the field vane undrained shear strength of sensitive clay to the fine particles' content (particles less than $2 \mu \mathrm{m}$ ), Atterberg limits, water content, liquidity index and the effective stress at the investigated depth. Moreover, no comparison was carried out in order to establish a correlation between the undrained shear strength of sensitive clay as determined by the field vane test and the Swedish cone.

In this investigation, relationships between the field undrained shear strength of sensitive clay and some laboratory soil properties was developed. The soil properties consisted of the percentage of fine particles (less than $2 \mu \mathrm{m}$ ), the moisture content and the Atterberg limits. Furthermore, a correlation was proposed associating between the undrained shear strength of sensitive clay as obtained by the field vane test and the laboratory cone penetration test (Swedish cone). In addition, some applications of the proposed correlation on some geotechnical problems were included, such as the determination of the consistency and the bearing capacity of a clay layer. Comparison of the results of the developed correlations with the experimental results of the present investigation and the results reported in the literature was undertaken.

Worthwhile to note that, the developed correlations can be used to estimate the field undrained shear strength of sensitive clays. This parameter is imperative in the design and analysis of any foundation system and retaining wall, and the assessment of slope stability. The application of the findings of the present investigation will reduce the cost and the time span of any geotechnical investigation conducted in cohesive soils (i.e. clayey soils).

\section{Experimental Work}

The clay studied is that of the Champlain Sea, which constitutes the majority of the surface deposits encountered in the Saint-Laurent, Quebec (Réginensi, 2009). According to Locat, Lefebvre \& Ballivy (1984), the mineralogical composition of these soils is dominated by several minerals, including quartz, plagioclases, microcline and hornblende, and contains few clay minerals.

Firstly, the soil samples of Champlain clay were collected from the Saint-Laurent region and the island of Montreal situated in the province of Quebec (Canada). Next, the physical properties of the clayey soil, beside the sieve analysis and the Atterbeg limits of the soils were experimentally determined. Thirdly, the undrained shear strength of the clay was determined in the laboratory using the Swedish cone. Fourthly, the in situ undrained shear strength of the Champlain clay was tested and obtained using the field vane test. These different tests will be discussed in detail in the following sections.

Grain size distribution of the Champlain clay was performed by sieve analysis and sedimentation method (i.e. hydrometer method). It was in the accordance with ASTM D6913 and ASTM D7928. The liquid and plastic limits were conducted on the material passing sieve \#40 using distilled water in accordance with ASTM D4318. The moisture content was measured in accordance with ASTM D2216-19. It is defined as the ratio between the weights of water present in the soil mass and the dry soil.

Based on the results of the sieve analysis performed by sedimentation, the percentage of clay (particles less than 0.002 $\mathrm{mm}$ ) in the tested samples is arranging between $47.0 \%$ and $69.3 \%$. The percentage of silt (particles less than $0.08 \mathrm{~mm}$ ) is varying between $53.0 \%$ and $30.7 \%$. This indicates that the soils analyzed are mainly composed of fine-textured soils (clay and silt). According to the results of the Atterberg limits tests, the liquidity limit of the clay is ranging between 37.6 to $73.0 \%$, and the plasticity limit is in the range of 21.9 to $44.5 \%$. Based on these results, the Champlain clay can be classified as $\mathrm{CH}$ (high plasticity soil). The natural moisture content of the deposit varies between 44.7 and $70.9 \%$. Thus, the natural water contents are above the liquidity limit, which is indicating that the clay is sensitive. These results are in concordance with the data reported by Réginensi (2009).

The undrained shear strength of the clay was determined in the laboratory on the same samples using the cone penetrometer test (the Swedish cone). The Swedish cone is a fast, simple and accurate method to determine the undrained shear strength and sensitivity of intact and remoulded clays. This very simple test allows obtaining very quickly an order of magnitude of the value of the undrained shear strength of a cohesive undisturbed soil. The instrument is mainly used for the determination of $C_{u}^{\text {cone }}$ of clays. It serves also in determining the sensitivity of and the liquidity of clays. 
A cone of known apex angle and mass $(m)$ is held on the surface of the soil sample. The cone is then suspended and released by the push-button mechanism, and its sinking $(H)$ into the soil is monitored. The test capability covers a range of shear forces from 0 to $200 \mathrm{kPa}$. The undrained shear strength is estimated by the following relationship (Lemos \& Pires, 2017):

$$
C_{u}^{\text {cone }}=K^{\prime} \frac{m \times g}{H^{2}}
$$

Where:

$C_{u}^{c o n e}=$ The undrained shear strength of the soil determined by Swedish cone (in $\mathrm{kPa}$ ),

$m=$ Mass of the cone $(m=100 \mathrm{~g})$

$H=$ Cone penetration depth $(\mathrm{mm})$

$g=$ Terrestrial acceleration $(g=9.81 \mathrm{~m} / \mathrm{s})$

$K^{\prime}=$ a dimensionless constant which depends on the angle at the apex of the cone $\left(30^{\circ}\right)$ and the degree of remolding of the soil.

As mentioned previously, the vane test was used to determine the undrained shear strength of the tested clay in the field. The field vane test gives an indication of the undrained shear strength for fine saturated soils (clays). The test is applicable to fine soils with undrained shear strengths of less than $200 \mathrm{kPa}$ (ASTM D2573). The test is a moderately fast and economical in-situ method for determining the undrained shear strength of soft to stiff clays. The test results are not reliable if the clay contains a significant amount of sand. The vane test used in this investigation consists of a stainless steel pallet with four blades attached to a steel rod. The height of the blade, which is twice its overall width, is equal to $13 \mathrm{~cm}$. The test was performed from the bottom of a borehole. The test involves driving a four-bladed paddle into a layer of clay and slowly rotating this paddle and measuring the resisting torque. The torque is measured at regular time intervals and the test is performed at a slower rate of $10^{\circ}$ per minute, and continues until a maximum torque is reached and the vane rotates rapidly for several seconds.

The undrained shear strength of the saturated clayey soil is proportional to the applied torque and to the dimensions of the pallet. The shear strength is determined by equating the torque at moments corresponding to the total shear strength at the sides and ends of the cylindrical shear failure surface. The undrained shear strength is estimated by the following expression (ASTM D 2573-01, 2001):

Where:

$$
C_{u}^{\text {vane }}=9,82 \times C \times K^{\prime \prime} \times\left(a_{s}-a_{f}\right)
$$

$C_{u}^{\text {vane }}=$ The undrained shear strength of the soil determined by the field vane test (in $\mathrm{kPa}$ ),

$C=$ Pallet shape constant $(C=0.103$ for the pallet used $6.5 \times 13 \mathrm{~cm})$,

$K "=$ Calibration constant of the torque recording head (in $\mathrm{kgm} / \mathrm{cm}$ )

$a_{s}=$ Distance in mm between the zero torque reference line and the peak of the curve obtained,

$a_{f}=$ Distance in $\mathrm{mm}$ between the zero torque reference line and the arc of the circle described during the first 15 degrees of rotation (corresponding to the friction of the rod).

In order to facilitate the application of the present findings by a wide range of users and for simplicity, the different technical terms used in this investigation were defined in Table A1 (Appendix A).

\section{Test Results and Analysis}

The results obtained from the in situ and laboratory tests described in the previous section were grouped and analysis in order to develop two different expressions which can be used to predict the field undrained shear strength of a sensitive clay, (i.e. $C_{u}^{v a n e}$ ).

The variation of the ratio $\frac{\mathcal{C}_{u}^{\text {vane }}}{\sigma^{\prime}}$ with the inverse of the clay activity is presented in Figure 1. It is clear from this figure that, the ratio $\frac{C_{u}^{\text {vane }}}{\sigma^{\prime}}$ increases when the inverse of the activity increases. So, it can be stated that this ratio decreases with increasing the clay activity. Moreover, this ratio is proportional to the inverse of the clay activity, and the 
relationship can be considered as linear with a coefficient of correlation $R=0.872$. The relationship can be presented by the following equation:

$$
\left(\frac{C_{u}^{\text {vane }}}{\sigma^{\prime}}\right)_{1}=0.273 \times \frac{1}{A_{c}}+0.161
$$

Where:

$\frac{C_{u}^{\text {vane }}}{\sigma^{\prime}}=$ ratio between the undrained shear strength and the effective stress at the sampling depth,

$A_{c}=$ clay activity.

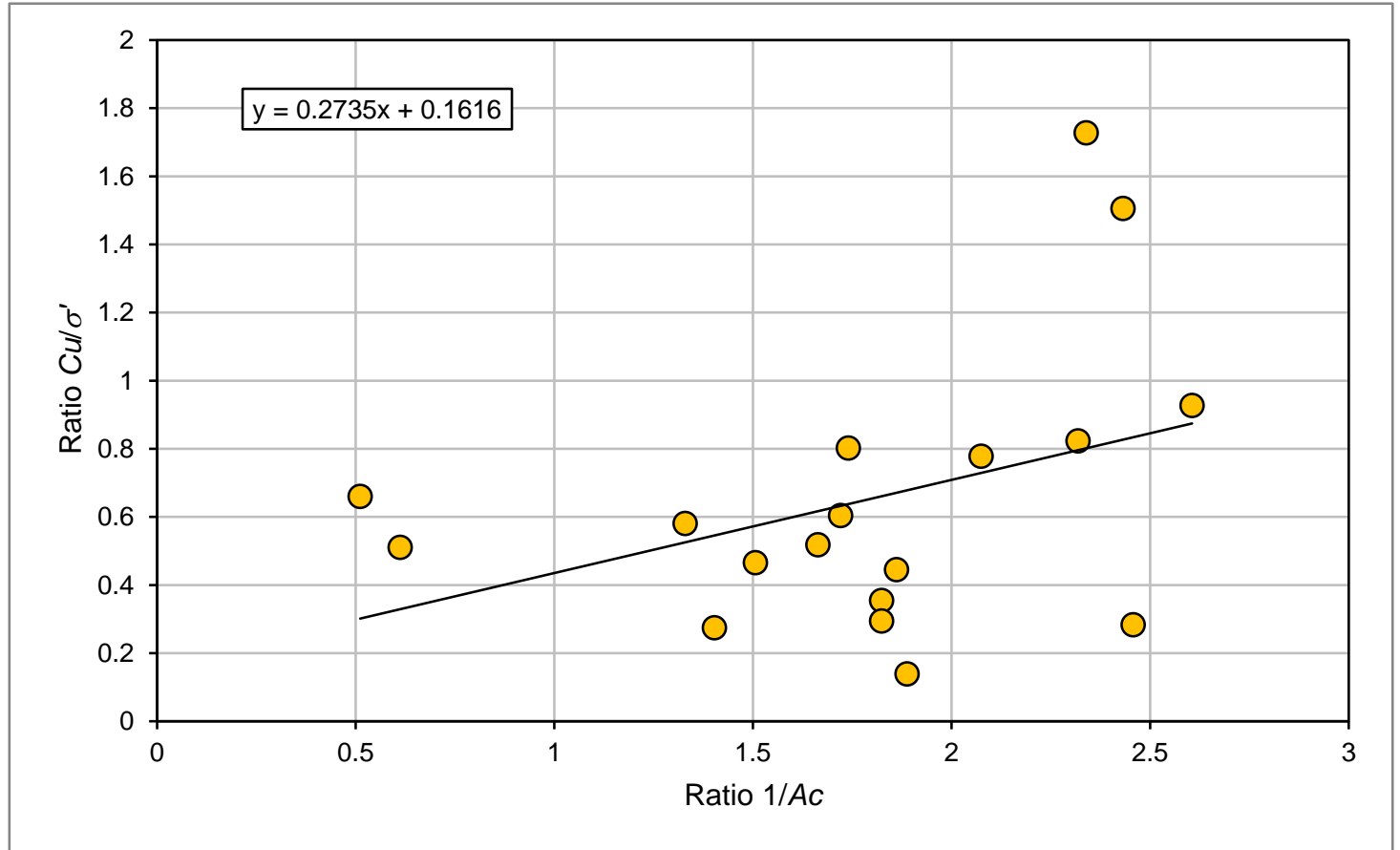

Figure 1. Variation of the ratio $\frac{c_{u}^{\text {vane }}}{\sigma^{\prime}}$ with $\frac{1}{A_{c}}$

Figure 2 shows the variation of the ratio $\frac{c_{u}^{\text {vane }}}{\sigma^{\prime}}$ versus the liquidity index. It can be noted from this figure that this ratio decreases with increasing the liquidity index. The relationship can be classified as logarithmic function, as follows:

$$
\left(\frac{C_{u}^{\text {vane }}}{\sigma^{\prime}}\right)_{2}=-0.43 \times \operatorname{Ln}(L I)+0591
$$

Where:

$L I=$ liquidity index. 


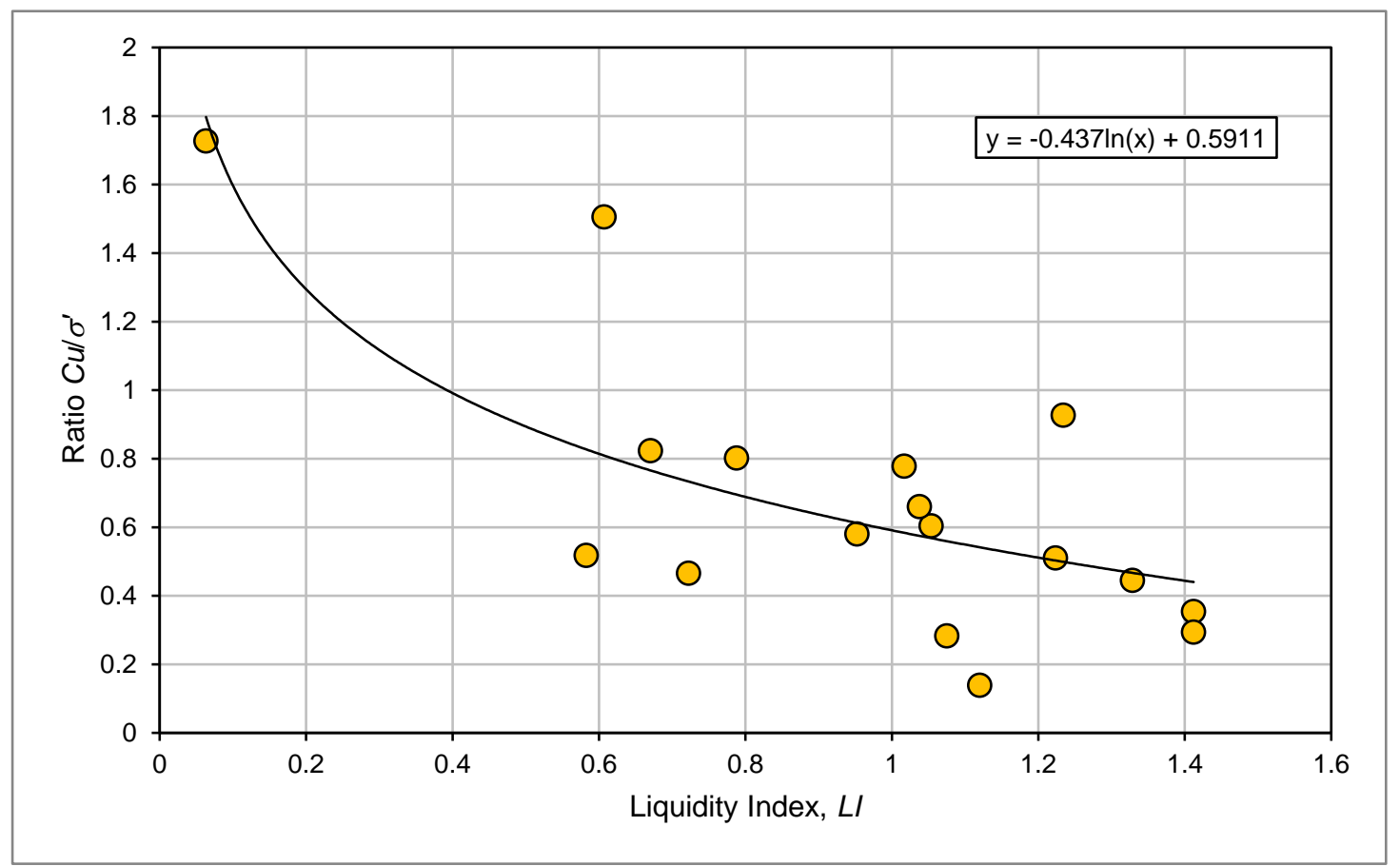

Figure 2. Variation of the ratio $\frac{C_{u}^{\text {vane }}}{\sigma^{\prime}}$ with $L I$

Figure 3 represents the variation of the ratio $\frac{C_{u}^{\text {vane }}}{\sigma^{\prime}}$ against the ratio $\frac{L L}{P I}$. This variation also obeys to a logarithmic function. It can be represented by the following expression:

$$
\left(\frac{C_{u}^{\text {vane }}}{\sigma^{\prime}}\right)_{3}=1.315 \times \operatorname{Ln}\left(\frac{L L}{P I}\right)-0.176
$$

Where:

$L L=$ liquidity limit.

$P I=$ plasticity index

The variation of the ratio $\frac{c_{u}^{\text {vane }}}{\sigma^{\prime}}$ with the ratio $\frac{P L}{P I}$ is illustrated in Figure 4. It can be noted from this figure that the ratio $\frac{c_{u}^{\text {vane }}}{\sigma^{\prime}}$ increases by increasing the ratio $\frac{P L}{P I}$, following the subsequent relationship:

$$
\left(\frac{C_{u}^{\text {vane }}}{\sigma^{\prime}}\right)_{4}=0.672 \times \operatorname{Ln}\left(\frac{P L}{P I}\right)+0.753
$$

Where:

$P L=$ plasticity limit. 
$P I=$ plasticity index

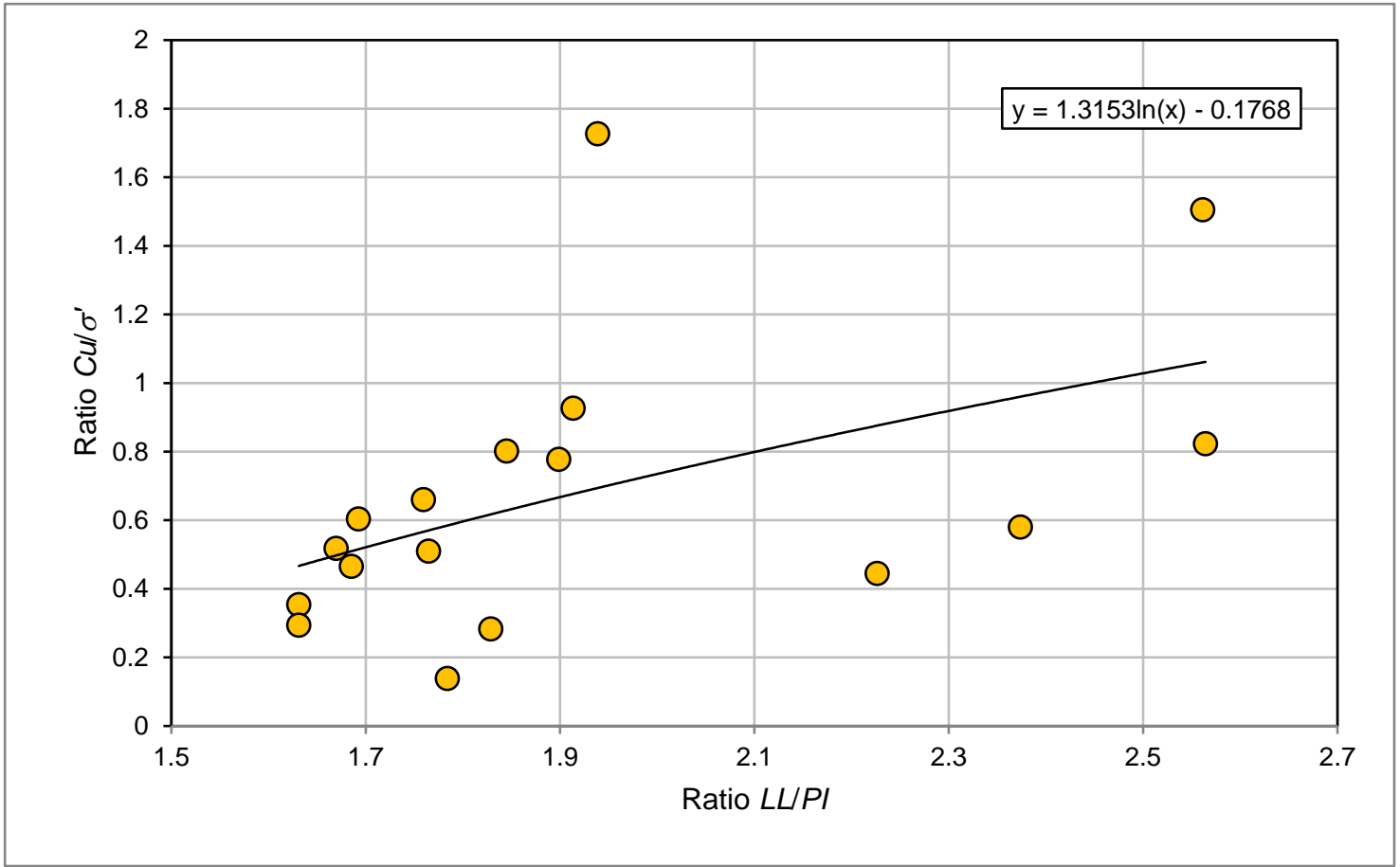

Figure 3. Variation of the ratio $\frac{C_{u}^{\text {vane }}}{\sigma^{\prime}}$ with $\frac{L L}{P I}$

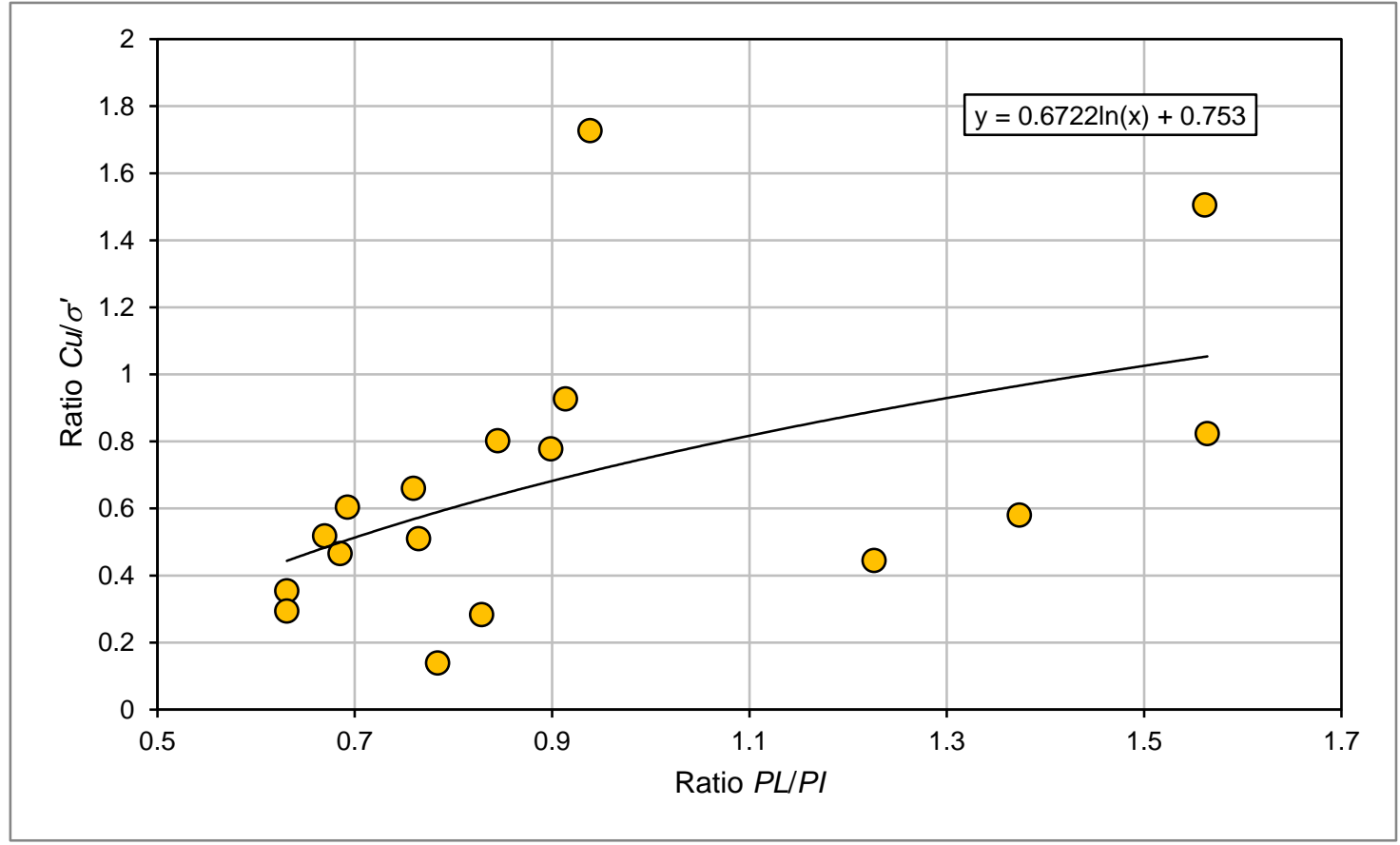

Figure 4. Variation of the ratio $\frac{c_{u}^{\text {vane }}}{\sigma^{\prime}}$ with $\frac{P L}{P I}$ 
Therefore the first expression which correlate between $C_{u}^{v a n e}$ and some properties of sensitive clays, such as the activity, the Atterberg limits, the liquidity index, and the effective stress is presented by the following expression:

$$
\frac{C_{u}^{\text {vane }}}{\sigma^{\prime}}=\frac{1}{n} \sum_{i=1}^{n}\left(\frac{C_{u}^{\text {vane }}}{\sigma^{\prime}}\right)_{i}
$$

Where:

$n=$ number of soil parameters considered (e.g. $n=4$ in case all soil parameters examined in the present investigation are considered).

Furthermore, based on the results presented in Figures 1 to 4 and using a least square regression, the following expression (Equation 8) was established for the estimation of the field undrained shear strength of sensitive clay:

$$
\frac{\mathcal{C}_{u}^{\text {vane }}}{\sigma^{\prime}}=\frac{0.07}{A_{c}}-0.11 \times \operatorname{Ln}(L I)+0.33 \times \operatorname{Ln}\left(\frac{L L}{P I}\right)+0.17 \times \operatorname{Ln}\left(\frac{P L}{P I}\right)+0.33
$$

Where:

$C_{u}^{\text {vane }}=$ The undrained shear strength of the soil determined by the field vane test (in kPa),

$\sigma^{\prime}=$ effective stress in the clay at the investigated depth $(\mathrm{kPa})$,

$A_{c}=$ Activity of clay,

$L I=$ Liquidity index,

$L L=$ Liquidity limit $(\%)$,

$P L=$ Plasticity limit $(\%)$,

$P I=$ Plasticity Index $(\%)$.

Consequently, it can be concluded that for the design of foundation systems, retaining walls or the assessment of slope stability, the field undrained shear strength of sensitive clay $C_{u}^{v a n e}$ can be taken as the minimum of the values determined by Equations (7) and (8).

The second expression, developed from the obtained results, associates between $C_{u}^{v a n e}$ and the undrained shear strength of sensitive clay determined by the Swedish cone (i.e. $C_{u}^{\text {cone }}$ ). For this purpose, a comparison between the results of the field vane test and the cone penetration test (Swedish cone) was carried out. The results obtained from this comparison are shown in Figure 5. This figure shows that the results of the field vane and the Swedish cone can be correlated by the following expression:

$$
C_{u}^{\text {vane }}=1,0678 \times C_{u}^{\text {cone }}+4,1283
$$

Where:

$C_{u}^{\text {vane }}=$ Undrained shear strength of clay determined in the field by the Vane test

$C_{u}^{\text {cone }}=$ Undrained shear strength of clay determined in the laboratory by the Swedish cone test

The correlation coefficient of this expression is in the order of $R=0.85$, which is practically acceptable in the field of geotechnical engineering. It should be noted that other curve trends were tried (including the exponential, logarithmic, power and polynomial curve), but it is the linear regression which gave the highest correlation coefficient.

Compared to the field vane test, the correlation established shows that the Swedish cone underestimates the value of the undrained shear strength of the Champlain sensitive clay by 8 to $10 \%$, when the clay is stiff to hard. However, for soft to firm clay, this range is in the order of 10 to $32 \%$. 


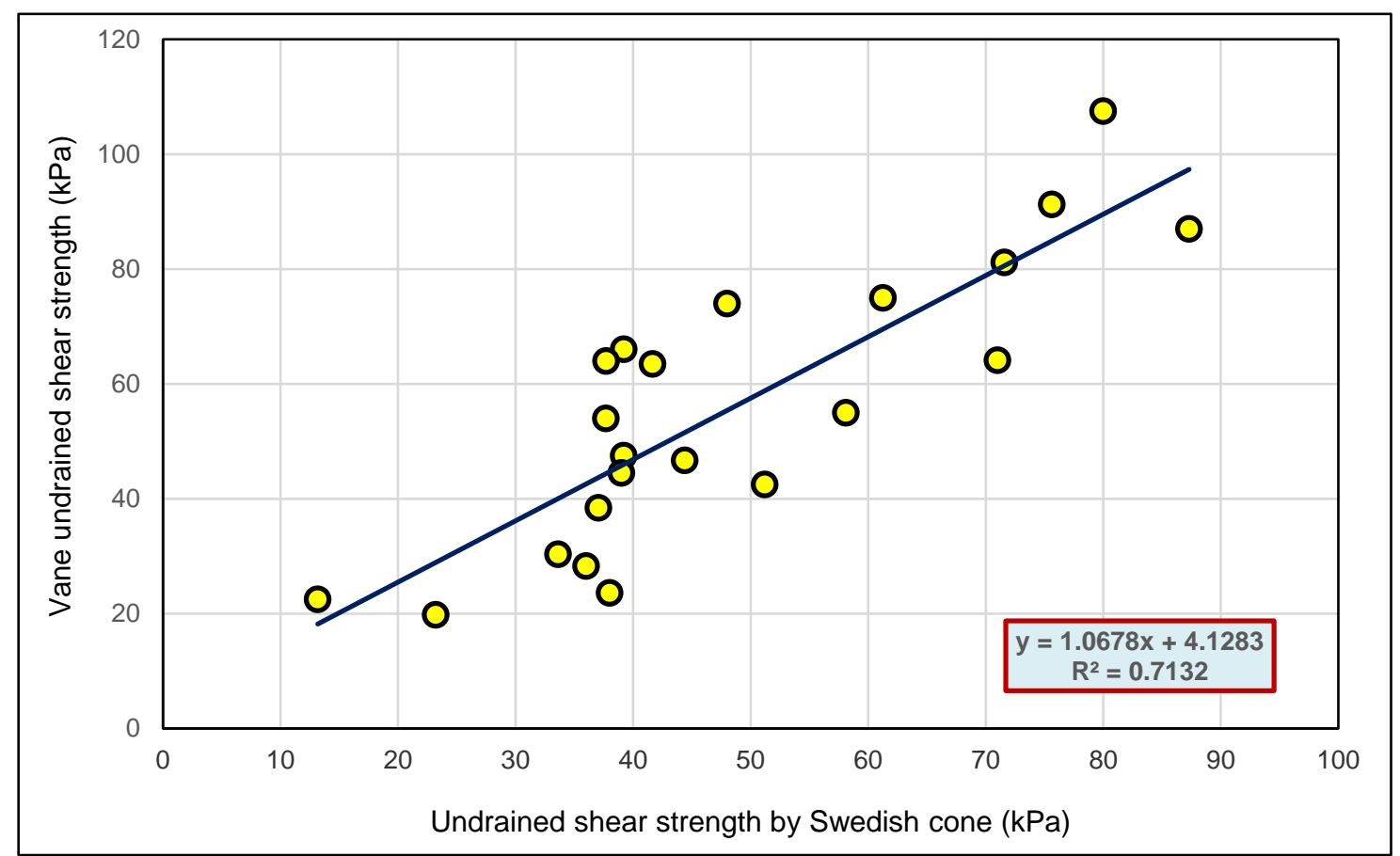

Figure 5. Variation of vane undrained shear strength of clay versus Swedish cone

The knowledge of the consistency of a clay layer and the determination of its ultimate bearing capacity are both essential elements for the design of a foundation system for a civil engineering structure. The net ultimate bearing capacity of an isolated footing placed on a clay layer can be determined by the following simplified relationship (Canadian Foundation Engineering Manual, 2006):

$$
q_{u}^{\text {vane }}=5,14 \times C_{u}^{\text {vane }} \times\left(1+0,2 \times \frac{D}{B}\right) \times\left(1+0,2 \times \frac{B}{L}\right)
$$

Where:

$q_{u}^{\text {Vane }}=$ Net ultimate bearing capacity obtained from the vane test

$B=$ Footing width

$L=$ Footing length

$D=$ Embedment depth of the footing

Replacing Equation (9) in (10), we get:

$$
q_{u}^{\text {vane }}=1,01678 \times q_{u}^{\text {cone }}+21,22 \times\left(1+0,2 \times \frac{D}{B}\right) \times\left(1+0,2 \times \frac{B}{L}\right)
$$

For simplicity, it is more convenient to present Equation (6) by the following relationship:

$$
q_{u}^{\text {vane }} \approx q_{u}^{\text {cone }}+K
$$

Where

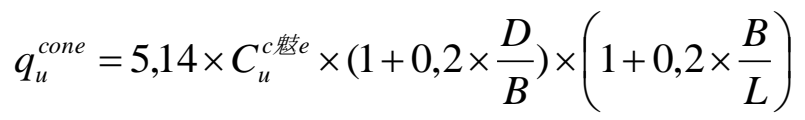




$$
K=21,22 \times\left(1+0,2 \times \frac{D}{B}\right) \times\left(1+0,2 \times \frac{B}{L}\right)
$$

The factor $K$ depends on the footing geometry (i.e. length, $L$ and width, $B$ ) and its embedment depth in the clay layer. To facilitate the estimation of this factor, Figures 6 and 7 were addressed. Figure 6 represents the case of an embedment depth $D=1.5 \mathrm{~m}$; whereas Figure 7 is for case $D=1.8 \mathrm{~m}$. However, for embedment depths less than $1.5 \mathrm{~m}$, Table 1 can be used to estimate the value of the factor $K$.

As mentioned previously, determining the consistency of clay is an important element in a geotechnical investigation. The consistency of clay is generally determined based on the vane undrained shear strength, which is considered the reference test (column 2, Table 2). Nevertheless, in the case of a project where the Swedish cone is used to determine the undrained shear strength, it is suggested to proceed with the values grouped in column 3 of the same table (Table 2). These values were deduced from the correlation represented by equation 4 .

The field and laboratory data of different samples taken from different sites of the Saint-Laurent region and the Montreal island were used to validate Equations (8) and (9). Furthermore, some data reported in literature were used to validate the developed equations. A comparison between measured and calculated values of the vane undrained shear strength obtained respectively by field tests and by Equations (8) and (9) was undertaken. The results of this comparison are shown in Figures. 8 and 9, where acceptable agreement is apparent.

Table 1. The different values of the Factor $K(\mathrm{kPa})$, for $D=0.6 ; 0.9$ and $1.2 \mathrm{~m}$

\begin{tabular}{|c|c|c|c|c|c|c|c|c|c|c|c|c|}
\hline \multirow[b]{3}{*}{$B(\mathbf{m})$} & \multicolumn{4}{|c|}{$D=0.6 \mathrm{~m}$} & \multicolumn{4}{|c|}{$D=0.9 \mathrm{~m}$} & \multicolumn{4}{|c|}{$D=1.2 \mathrm{~m}$} \\
\hline & \multicolumn{4}{|c|}{$L / B$} & \multicolumn{4}{|c|}{$L / B$} & \multicolumn{4}{|c|}{$L / B$} \\
\hline & 1 & 2 & 5 & $\infty$ & 1 & 2 & 5 & $\infty$ & 1 & 2 & 5 & $\infty$ \\
\hline 0.6 & 30.56 & 28.01 & 6.48 & 25.46 & 3.10 & 30.34 & 3.6 & 27.59 & 35.65 & 32.68 & 0.90 & 29.71 \\
\hline 0.9 & 28.86 & 26.45 & 25.01 & 24.05 & 30.56 & 28.01 & 26.48 & 25.46 & 32.25 & 29.57 & 27.95 & 26.88 \\
\hline 1.2 & 28.01 & 25.68 & 24.28 & 23.34 & 29.28 & 26.84 & 25.38 & 24.40 & 30.56 & 28.01 & 26.48 & 25.46 \\
\hline 1.5 & 27.50 & 25.21 & 23.83 & 22.92 & 28.52 & 26.14 & 24.72 & 23.77 & 29.54 & 27.08 & 25.60 & 24.61 \\
\hline 1.8 & 27.16 & 24.90 & 23.54 & 22.63 & 28.01 & 25.68 & 24.28 & 23.34 & 28.86 & 26.45 & 25.01 & 24.05 \\
\hline 2.1 & 26.92 & 24.68 & 23.33 & 22.43 & 27.65 & 25.34 & 23.96 & 23.04 & 28.37 & 26.01 & 24.59 & 23.64 \\
\hline 2.4 & 26.74 & 24.51 & 23.17 & 22.28 & 27.37 & 25.09 & 23.72 & 22.81 & 28.01 & 25.68 & 24.28 & 23.34 \\
\hline 2.7 & 26.60 & 24.38 & 23.05 & 22.16 & 27.16 & 24.90 & 23.54 & 22.63 & 27.73 & 25.42 & 24.03 & 23.11 \\
\hline 3.0 & 26.48 & 24.28 & 22.95 & 22.07 & 26.99 & 24.74 & 23.39 & 22.49 & 27.50 & 25.21 & 23.83 & 22.92 \\
\hline
\end{tabular}

Table 2. Determination of Clay Consistency

\begin{tabular}{c|c|c}
\hline \multirow{2}{*}{ Consistency } & \multicolumn{2}{|c}{ Undrained shear strength, $\boldsymbol{C}_{\boldsymbol{u}}(\mathbf{k P a})$} \\
\cline { 2 - 3 } & Vane Test & Swedish cone \\
\hline Very Soft & $<12$ & $<7$ \\
\hline Soft & $12-25$ & $7-19$ \\
\hline Firm & $25-50$ & $19-42$ \\
\hline Stiff & $50-100$ & $42-89$ \\
\hline Very Stiff & $100-200$ & $89-183$ \\
\hline Hard & $>200$ & $>183$ \\
\hline
\end{tabular}




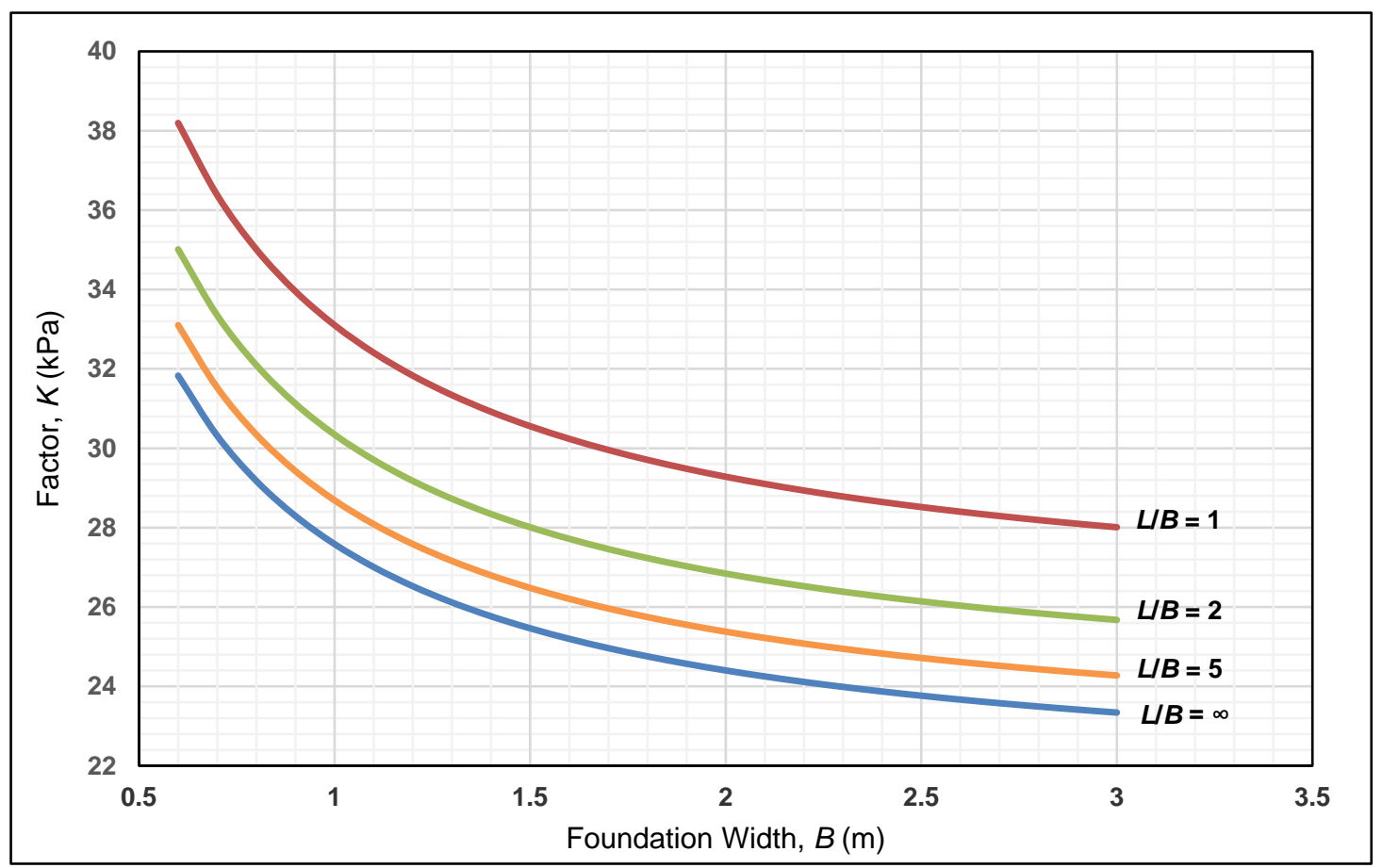

Figure 6. Variation of the factor $K$ in terms of the foundation width $B$ (for $D=1.5 \mathrm{~m}$ )

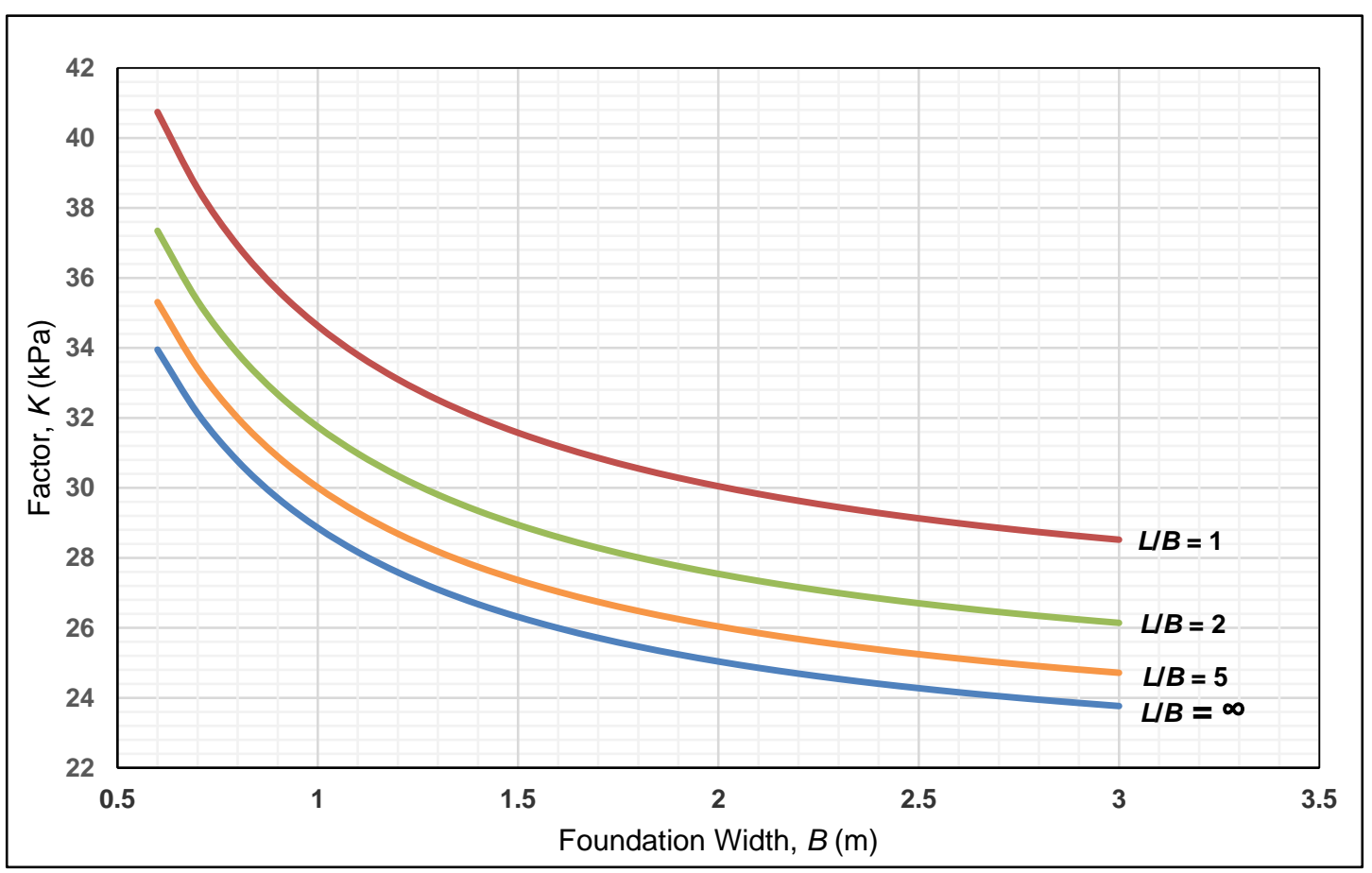

Figure 7. Variation of the factor $K$ in terms of the foundation width $B$ (for $D=1.8 \mathrm{~m}$ ) 


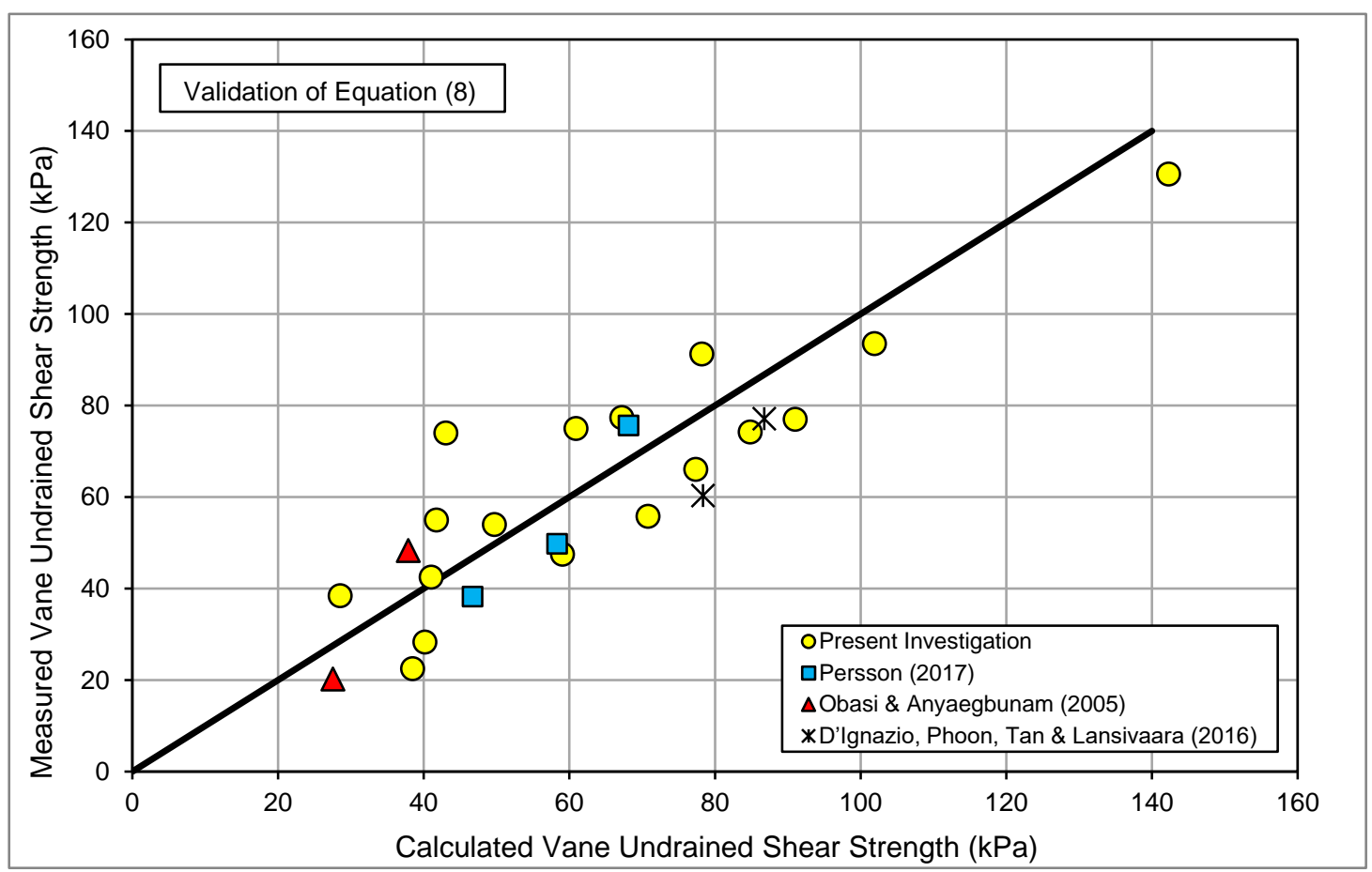

Figure 8. Comparison between Calculated and Measured Vane Undrained Shear Strength Results (Equation 8)

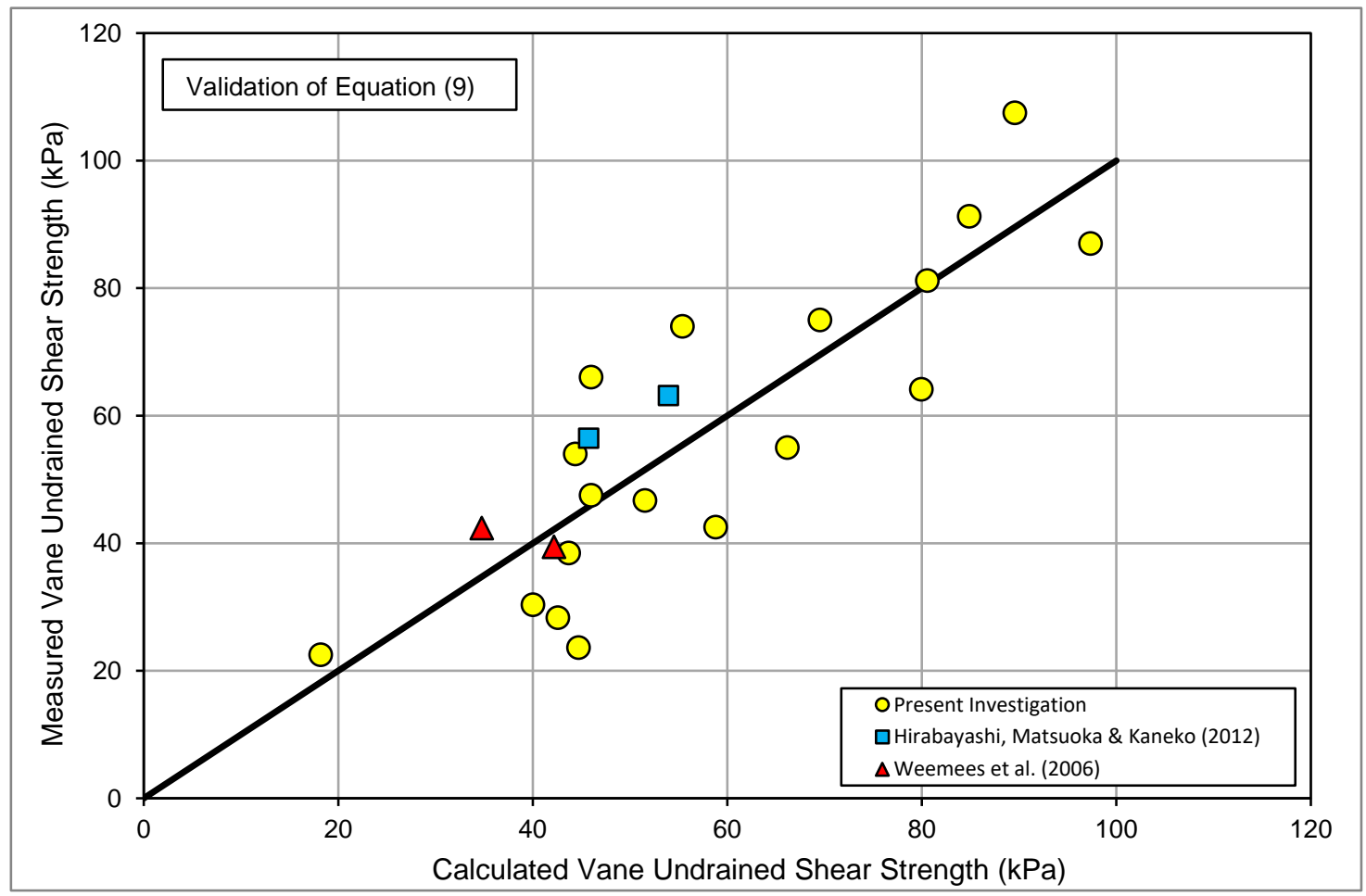

Figure 9. Comparison between Calculated and Measured Vane Undrained Shear Strength Results (Equation 9)

However, although the developed models were validated against some data reported in literature for different type of clays, it is important to mention that the findings of the present investigation are based on sensitive clays with mineralogical compositions dominated by quartz, plagioclases, microcline and hornblende, and contains few clay minerals. The amount of data is limited and may thus not be representative for clays in general. The sites from where data have been obtained are limited to clay of Champlain Sea (Quebec, Canada. The hypotheses are tested, results obtained and conclusions drawn for the specific samples. 


\section{Conclusion}

The conclusions drawn from this study can be summarized as follows:

1- Relationships between the field undrained shear strength of sensitive clay and some laboratory soil properties, such as the percentage of fine particles (less than $2 \mu \mathrm{m}$ ), the moisture content and the Atterberg limits, were developed (Equations 7 and 8). The field undrained shear strength of sensitive clay can be taken as the minimum of the values determined by these two equations.

2- A correlation was proposed associating between the undrained shear strength of sensitive clay as obtained by the field vane test and the laboratory cone penetration test, i.e. Swedish cone (Equation 9).

3- Compared to the field vane test, the Swedish cone test underestimates the value of the shear strength of sensitive clay by 8 to $10 \%$ when the consistency of the clay varies from stiff to hard. However, for soft to relatively stiff clays, this range is in the order of 10 to $32 \%$.

4- In the case where the undrained shear strength of the clay is obtained by the Swedish cone test, the expression represented by Equation 12 should be used to estimate the net ultimate bearing capacity of the clay layer.

5- Based on the undrained shear strength of clay obtained by the Swedish cone test, it is suggested to determine the consistency of sensitive clay from the new limit values grouped in column 3 of Table 2.

\section{References}

ASTM D 2573-01 (2001). Standard Test Method for Field Vane Shear Test in Cohesive Soil. ASTM, Philadelphia, Pennsylvania, USA.

Canadian Foundation Engineering Manual (2006). Published by the Canadian Geotechnical Society, $4^{\text {th }}$ Edition, BiTech Publishers Ltd.

Cangir, B., \& Dipova, N. (2017). Estimation of undrained shear strength of Konyaalti silty clays. Indian Journal Geo. Mar. Sci., 46(3), 513-520.

Chacko, J., \& Jacob, D. S. (2018.) Study on strength characteristics of Kuttanad clay based on its water content and consistency limits. International Research Journal of Engineering and Technology, 5(4), 3221-3225.

Ching, J., \& Phoon, K. K. (2014). Transformations and correlations among some clay parameters - the global database. Canadian Geotechnical Journal, 51(6), 663-685. https://doi.org/10.1139/cgj-2013-0262

D’Ignazio, M., Phoon, K. K., Tan, S. A., \& Länsivaara, T. T. (2016). Correlations for undrained shear strength of Finnish soft clays. Canadian Geotechnical Journal, 53(10), 1628-1645. https://doi.org/10.1139/cgj-2016-0037

D’Ignazio, M., Phoon, K., Tan, S. A., Länsivaara, T., \& Lacasse, S. (2017). Reply to the discussion by Mesri and Wang on Correlations for undrained shear strength of Finnish soft clays. 1, 54(April), 749-753. https://doi.org/10.1139/cgj-2017-0114

Fehmarnbelt (2011). Ground Investigation Report. GDR 00.1-001 with additional data from GEO (2011) GDR 18.0-004. Advanced Laboratory Testing, Glacial Deposits and GDR 18.0-005, Advanced Laboratory Testing, Clays of Palaeogene Origin.

Hernandez-Martinez, F. G., \& Karlsrud, K. (2013). Strength and deformation properties of Norwegian clays from laboratory tests on high-quality block samples. NRC Research press, 1293(23), 1273-1293. https://doi.org/10.1139/cgj-2013-0298

Jacob, K., \& Hari, G. (2016). Study on the relationship of compression index from water content, Atterberg limits and field density for Kuttanad clay. International Journal of Innovative Research and Technology, 3(4), 33-38.

Jonsson, M., \& Sellin, C. (2012). Correction of shear strength in cohesive soil - A comparison focused on vane tests in west Sweden. Gothenburg.

Karakan, E., \& Demiri, S. (2018). Relationship Between Undrained Shear Strength with Atterberg Limits of Kaolinite/Bentonite-Quartz Mixtures. International Journal of Engineering Research and Development, 10(3). https://doi.org/10.29137/umagd.480150

Lemos, S. G. F. P., \& Pires, P. J. M. (2017). The Undrained Strength of Soft Clays Determined from Unconventional and Conventional Tests. Soils and Rocks, São Paulo, 40(3), 291-301. https://doi.org/10.28927/SR.403291

Locat, J., Lefebvre, G., \& Ballivy, G. (1984). Mineralogy, chemistry, and physical properties interrelationships of some sensitive clays from eastern Canada. Canadian Geotechnical Journal, 21, 530-540. https://doi.org/10.1139/t84-055

Mengistu, J. (2017). Correlating liquidity index with vane-shear strength of clays in Addis Ababa. Master Thesis. Addis Ababa University Institute of Technology, Ethiopia. 
Obasi, N. L., \& Anyaegbunam, A. J. (2005), Correlation of the undrained shear strength and plasticity index of tropical clays. Nigerian Journal of Technology, 24(2), 1-15.

Persson, E. (2017). Empirical correlation between undrained shear strength and preconsolidation pressure in Swedish soft clays. MSc. Thesis, Division of Soil and Rock Mechanics, Royal Institute of Technology, Stockholm.

Réginensi, F. (2009). Évolution Géotechnique de l'eau Interstitielle d'une Argile de la Mer de Champlain. Mémoire de Maîtrise ÉS Sciences appliquées (Génie Minéral), École Polytechnique de Montréal.

Schaeffers, J., \& Weemees, I. (2012). Comparison of in-situ shear strength measurement techniques of soft clays. 20th Vancouver Geotechnical Society Symposium, Soft Ground Engineering, Vancouver (BC).

Shimobe, S., \& Spagnoli, G. (2019). Some relations among fall cone penetration, liquidity index and undrained shear strength of clays considering the sensitivity ratio. Bulletin of Engineering, Geology and Environment, 78(7), 5029-5038. https://doi.org/10.1007/s10064-019-01478-2

Shimobe, S., \& Spagnoli, G. (2020). Relationships between undrained shear strength, liquidity index, and water content ratio of clays Bulletin of Engineering Geology and the Environment, 79, 4817-4828. https://doi.org/10.1007/s10064-020-01844-5

Sorensen, K. K. (2013). Correlation between drained shear strength and plasticity index of undisturbed overconsolidated clays. $18^{\text {th }}$ International Conference on Soil Mechanics and Geotechnical Engineering, Paris.

Tanaka, H., Hirabayashi, H., Matsuoka, T., \& Kaneko H. (2012). Comparison of Field Vane, CPT, and Laboratory Strength Data at Santa Barbara Channel Site. Soils and Foundations, 52(4), 590-599. https://doi.org/10.1016/j.sandf.2012.07.002

Weemees, I., Howie, J., Woeller, D. J., Sharp, J., Cargill, E., \& Greig, J. (2006). Improved Techniques for the Insitu Determination of Undrained Shear Strength in Soft Clays, Proceedings of Canadian Geotechnical Conference, Vancouver, BC.

Westerberg, B., Müller, R., \& Larsson, S. (2015) 'Evaluation of undrained shear strength of Swedish fine-grained sulphide soils', Engineering Geology. Elsevier B.V., 188, 77-87. https://doi.org/10.1016/j.enggeo.2015.01.007 


\section{Appendix A}

Table A1. Definition of some technical terms used in the present investigation

\begin{tabular}{|c|c|c|}
\hline & Terms used & Definition \\
\hline 1 & Soil shear strength & Resistance of a soil to sliding and failure under an applied load \\
\hline 2 & The bearing capacity & $\begin{array}{l}\text { Bearing capacity of a soil is characterized by its resistance to } \\
\text { settlement due to soil cohesion and internal friction }\end{array}$ \\
\hline 3 & The stability of slopes & $\begin{array}{l}\text { Stability of slopes refers to the condition of inclined soil or } \\
\text { rock slopes to withstand or undergo movement }\end{array}$ \\
\hline 4 & The field vane test & $\begin{array}{l}\text { Field vane shear test is a method of measuring the shear strength } \\
\text { of cohesive soils (clay soils) in the field. }\end{array}$ \\
\hline 5 & Laboratory vane test & $\begin{array}{l}\text { Laboratory vane shear test for the measurement of shear } \\
\text { strength of clay soils. }\end{array}$ \\
\hline 6 & Triaxial vane test & \\
\hline 7 & Unconfined compression test & $\begin{array}{l}\text { Unconfined Compression Test is a laboratory test used to derive } \\
\text { the unconfirmed compressive strength of a clay or a rock } \\
\text { specimen. }\end{array}$ \\
\hline 8 & $\begin{array}{l}\text { Consistency penetrometer (noted } \\
\text { as the Swedish cone). }\end{array}$ & $\begin{array}{l}\text { A simple method to determine the consistency of different soils is } \\
\text { by means of a penetrometer }\end{array}$ \\
\hline 9 & The electric field vane test & \\
\hline 10 & $\begin{array}{l}\text { Undrained shear strength of } \\
\text { clays }\end{array}$ & $\begin{array}{l}\text { Undrained shear strength is the shear strength of a clay when } \\
\text { sheared at constant volume }\end{array}$ \\
\hline 11 & Plasticity index & The plasticity index $(P I)$ is a measure of the plasticity of a soil \\
\hline 12 & The Atterberg limits & $\begin{array}{l}\text { The Atterberg limits are a basic measure of the critical water } \\
\text { contents of a fine-grained soil: its shrinkage limit, plastic limit, } \\
\text { and liquid limit }\end{array}$ \\
\hline 13 & The pre-consolidation pressure & $\begin{array}{l}\text { Pre-consolidation pressure is the maximum effective vertical } \\
\text { overburden stress that a particular soil sample has sustained in the } \\
\text { past }\end{array}$ \\
\hline 14 & ASTM & $\begin{array}{l}\text { American Society of Testing Materials: Standards used or } \\
\text { followed for the different testing }\end{array}$ \\
\hline
\end{tabular}

\section{Copyrights}

Copyright for this article is retained by the author(s), with first publication rights granted to the journal.

This is an open-access article distributed under the terms and conditions of the Creative Commons Attribution license which permits unrestricted use, distribution, and reproduction in any medium, provided the original work is properly cited. 